\title{
PHYLOGENETIC APPROACH TO THE STUDY OF TRIATOMINES (TRIATOMINAE, HETEROPTERA)
}

\author{
TARTAROTTI, E. ${ }^{1}$, AZEREDO-OLIVEIRA, M. T. V. ${ }^{1}$ and CERON, C. R. ${ }^{2}$ \\ ${ }^{1}$ Departamento de Biologia, Instituto de Biociências, Letras e Ciências Exatas - IBILCE/UNESP, São José do Rio Preto, SP \\ ${ }^{2}$ Departamento de Química e Ciências Ambientais, Instituto de Biociências, Letras e Ciências Exatas - IBILCE/UNESP \\ São José do Rio Preto, SP \\ Correspondence to: Ester Tartarotti and Carlos Roberto Ceron, Instituto de Biociências, Letras e Ciências \\ Exatas de São José do Rio Preto - IBILCE-UNESP, Rua Cristóvão Colombo, 2265, CEP 15054-000, \\ São José do Rio Preto, SP, Brazil, e-mail: tartarot@bio.ibilce.unesp.br; ceron@qca.ibilce.unesp.br \\ Received June 9, 2004 - Accepted October 4, 2004 - Distributed May 31, 2006
}

\begin{abstract}
Triatomines are insects belonging to the Hemiptera order, Heteroptera suborder, Reduviidae family and Triatominae subfamily. All members of this subfamily are hematophagous. Triatomines evolved from Reduviidae predators and they are probably polyphyletic in origin. The combination of anatomical, physiological and ethological factors observed in this group, as well as the plesiomorphic and apomorphic characters that differentiate the five tribes and fourteen triatomine genera reinforce the polyphiletic hypotesis. However if we consider the five groups of triatomines, the Rhodniini, Cavernicolini, Bolboderini, Linshcosteini and Alberproseniini tribes constitute monophyletic groups, while the Triatomini tribe is considered polyphyletic. The New World is the center of triatomine diversity and seems to be the point of group origin. Of approximately 137 triatomine species, 105 are only found in the Americas. It is now considered that triatomines represent a polyphyletic group defined according to their convergent apomorphic hematophagous characters, which have appeared several times in Reduviidae. This study revises the phylogeny of these vectors of Chagas' disease, covering such topics as the origin of hematophagy in triatomines and ancestral proposal for the group.
\end{abstract}

Keywords: Heteroptera, Triatominae, Reduviidae, phylogeny.

\section{RESUMO}

\section{Abordagem filogenética em Triatomíneos (Triatominae, Heteroptera)}

Os triatomíneos são insetos pertencentes à ordem Hemiptera, subordem Heteroptera, família Reduviidae e subfamília Triatominae. Todos os membros desta subfamília são hematófagos. Os triatomíneos surgiram a partir de reduvídeos predadores e provavelmente têm origem polifilética. A combinação dos fatores anatômicos, fisiológicos e etológicos presentes no grupo, bem como os caracteres plésio e apomórficos que diferenciam as cinco tribos e os quatorze gêneros de triatomíneos reforçam a hipótese polifilética. As tribos Rhodniini, Cavernicolini, Bolboderini, Linshcosteini e Alberproseniini constituem grupos monofiléticos, per si, enquanto a tribo Triatomini é considerada polifilética. O Novo Mundo é claramente o centro de diversidade dos triatomíneos e possivelmente é a região de sua origem. Entre as aproximadamente 129 espécies desses insetos, 105 ocorrem somente nas Américas. Atualmente, os triatomíneos são considerados um grupo polifilético, definido com base em seus caracteres apomórficos convergentes relacionados à hematofagia. Acredita-se que este hábito alimentar tenha surgido várias vezes nos Reduviidae durante sua evolução. O presente trabalho faz uma revisão sobre a filogenia destes vetores da Doença de Chagas, aborda tópicos como a origem da hematofagia nos triatomíneos e ancestralidade proposta para o grupo.

Palavras-chave: Heteroptera, Triatominae, Reduviidae, filogenia. 
Triatomines are insects belonging to the Hemiptera order, Heteroptera suborder, Reduviidae family and Triatominae subfamily. All members of this subfamily are hematophagous, which is considered to be a recent characteristic in evolutionary terms. In relation to the taxonomy and phylogenesis of triatomines, it is interesting to point out that the Hemiptera order has dispersed representatives throughout the tropical and temperate regions. In this order more than 80 thousand species are described. Traditionally, Hemiptera is divided into two suborders, Homoptera and Heteroptera.

Some Homoptera and most Heteroptera are adapted to feeding on plant sap. Some insects of the Heteroptera suborder are predators on insects and on other invertebrates, sucking their hemolymph, while other Heteroptera have become hematophagous as for instance the Triatominae subfamily (Schofield \& Dolling, 1993).

Reduviidae is an ancient family, with fossil remains suggesting that the initial predatory forms might have derived from Hemipteran during the Permian/Triassic period. These forms preceded the hematophagous group which probably appeared together with the first mammals and birds during the Jurassic period, 50 million years ago. Reduviidae predators are widely distributed and their fossil remains have been found in amber from the Oligocene and Eocene periods (25-65 million years B.P.). In contrast, there is no evidence of fossil remains of hematophagous forms from those periods (Schofield, 2000).

It may be suggested that primitive predators and hematophagous Heteroptera developed from sap sucking insects (phytophagous), the ProtoHeteroptera, undergoing modifications in their buccal and digestive apparatus. The terrestrial groups developed into two main branches, Pentatomorpha and Cimicomorpha. These groups gave rise to predatorial forms such as Cimicidae, and hematophagous forms like Triatominae.

Triatomines probably evolved from Reduviidae predator groups. The Reduviidae early on in their evolution possibly fed on soft forms of invertebrate animals that inhabited vertebrate nests, such as caterpillars, larvae and spiders. Later they began to attempt perforating the skin of small vertebrates. It is possible that, in the first phase, hematophagy was optional, and, since the saliva of these insects had no anesthetic properties, the triatomines would have been driven to feed on newly born vertebrates, which would be attacked in a special form of predation. Later in this phase, starting with adaptations for hemolysis, the hematophagous process would have begun (Carcavallo et al., 1999).

To avoid the predatory vertebrates in the nests and burrows, it was necessary to make adaptations, such as cryptic behavior and inverse activity pattern, for feeding while the vertebrate is asleep. In predators, the saliva has a proteolytic effect, a characteristic that was lost by most of the hematophagous insects to make it possible to ingest blood by a painless bite. Hematophagy also requires a rapid compensation of the enormous amount of blood that triatomines ingest. The insect therefore excretes great amounts of water and salts immediately to reduce its weight. Another adaptation to hematophagy is the erythrocytic rupture and hemolytic process at the beginning of digestion (Carcavallo et al., 1999).

Primitive predatory behavior still occurs in many triatomines species, including T. rubrofasciata, which feeds on caterpillars, T. rubrovaria which can feed on spiders and silkworm and $T$. circummaculata, which feeds on vertebrates blood and cockroach hemolymph. Young nymphs of Eratyrus mucronatus preferentially feed on invertebrate animals, while nymphs in more advanced stages and adults feed on vertebrate's blood. Cannibalistic behavior can be a transitional stage between predation and hematophagy. There are reports of nymphs sucking blood from other nymphs in laboratory colonies. Such cleptohematophagous behavior occurs in Belminus herreri which obtains blood from species of recently fed Rhodnius. In short, all of these observations suggest that hematophagy is a recent characteristic in triatomines and that adaptations to this habit are still occurring. Triatomines are little different from Reduviidae predators, in habitat and forms, which also corroborates the argument that this group is a recent one. For mammals, the bite from Reduviidae predators tends to be very painful and can cause death, especially by anaphylactic shock in small animals. The same happens in the case of certain triatomines. For instance, the bite of $P$. geniculatus in pigs and humans in the Amazon leaves painful lesions and, in the case of 
T. rubrofasciata, there has been at least one report of human death (Schofield, 2000).

Gorla et al. (1997) consider that triatomines are polyphyletic in origin and they believe that hematophagy have appeared recently, associated with the evolution of vertebrate nests. The polyphyletic hypothesis suggests that the adaptative steps from free life predators to hematophagous feeding might have occurred several times, not only among different groups of Reduviidae, but also among other Hemiptera groups.

This hypothesis may explain the close relationship between genera and species of triatomines associated with certain vertebrates. For instance, Psammolestes associated with bird's nests, Dendrocolaptidae, Cavernicola pilosa barber with Chiroptera, Microtriatoma with the biocenosis of the great Bromeliads, $P$. geniculatus associated with the Edentates, and some species of the Triatoma protracta complex associated with the Neotoma genus. The polyphyletic hypothesis also helps to explain most of the anatomical differences found between some tribes and their notable similarity with taxa of other Reduviidae subfamilies. For example, Alberproseniini possesses morphological characteristics of the Cetherinae and Psammolestes possesses anatomical characteristics present in the Physoderinae subfamily. Among the most convincing studies, it has been discovered that there are fundamental differences in salivary components between Rhodniini and Triatomini, as well as differences in sensorial patterns, suggesting different origins for these two tribes. Therefore, the Triatominae subfamily should be assumed, more correctly, to be a utilitarian group, defined on the basis of their hematophagous habits and adaptations associated to this diet, and not a cladistic classification of individuals sharing a common ancestry (Carcavallo et al., 1999).

Some authors, including Usinger et al. (1966) believe, however, that the triatomines represent a monophyletic group and that their hematophagy have appeared only once. Gaunt \& Miles (2000) also postulate that the triatomines are of monophyletic origin, based on the appearance of a salivary protein (anti-thrombin).

The monophyletic hypothesis is not only difficult to support, but it also causes problems in the understanding of the insects' distribution, association with animals, source of feeding and adaptation to different habitats. The comparison between population and behavioral parameters, association with vertebrates and habitat, as well as their biogeographical characteristics support the hypothesis that triatomines probably appeared several times within the Reduviidae and that they represent species of polyphyletic origin, based on their apomorphic character with relation to hematophagy (Schofield, 1988; Lyman et al., 1999; Bargues et al., 2000, Marcilla et al., 2001).

The New World is clearly the center of triatomine origin and diversity. Of the approximately 137 triatomine species (Galvão, et al. 2003), 105 occur in this area. Of the fourteen genera, twelve are found exclusively in America: Alberprosenia, Belminus, Bolbodera, Cavernicola, Dipetalogaster, Eratyrus, Microtriatoma, Panstrongylus, Parabelmintos, Paratriatoma, Psammolestes and Rhodnius. Only two genera, Linshcosteus and Triatoma, occur in the Old World, and the Triatoma is also found in the New World. The Linshcosteus genus, with five species, is confined to the Indian subcontinent, seven species of Triatoma are present in Southeast Asia and one species, T. rubrofasciata, is cosmopolitan in the tropics. Its wide distribution can be explained by marine transport from the XVII century to the early XX century. This species is also present in the Brazilian northeast (Schofield \& Dolling, 1993). T. rubrofasciata is considered to be an ancestor of the other seven Triatoma species in Southeast Asia (T. Amicitiae, bouvieri, cavernicola, leopoldi, migrans, pugasi, sinica) because they share morphological characteristics and are all included in the Rubrofasciata group. Another interesting characteristic that confirms the hypothesis that T. rubrofasciata is an older species is related to its painful bite, considered a primitive characteristic (Schofield, 1988).

The almost total absence of triatomines in Africa, except T. rubrofasciata, probably brought to African ports by ships, suggests that the hematophagous evolution of Reduviidae in Africa was inhibited by the evolution of the hematophagous Anthocorideos, now known as Cimicidae, which had already occupied the available niches. The high degree of morphological specialization of Cimicidae suggests that they arose prior to the triatomines and that the latter evolved independently in America after the separation of 
the continents. This hypothesis is better than the view that triatomines may have appeared in Africa and, subsequently, become locally extinguished (Schofield, 2000).

The dispersion of triatomines by vertebrates was studied on $R$. prolixus in Central America. It is believed that these insects migrated from South America to Central America, transported by birds. Enzymatic and RAPD (Random Amplification of Polymorphic DNA) analyses corroborated this view, the limited genetic variability denoting the recent origin of populations from South America (Dujardin et al., 1998).

Similarly, the presence of Rhodnius prolixus in Mexico is associated with the migration of vertebrates. The expansion and distribution of T. infestans, for example, is closely related to human activity (Schofileld, 1988). The species is endemic in Bolivia and suffered dispersion by human action, their domiciliary invasion obeying an opportunist mechanism provided by the stimulus of shelter and feeding (Forattini, 1980).

In the triatomine group, the Rhodniini, Cavernicolini, Bolboderini, Alberproseniini and Linshcosteini tribes constitute monophyletic groups, that is, each tribe possesses an ancestral in common, while the Triatomini tribe is considered to be a polyphyletic group, with several ancestral giving origin to the tribe (Lent \& Wygodzinsky, 1979; Galvão et al., 2003). For example, the Panstrongylus species is included in the Triatomini tribe. Phylogenetic analyses revealed that the Triatoma and Panstrongylus genera were more closely related to each other than when compared with the Rhodnius genus (Stothard et al., 1998). Studies in nuclear rDNA ITS-2 sequences revealed a possible polyphyly of Panstrongylus species. The species $P$. megistus, $P$. geniculatus, $P$. rufotuberculatus, $P$. lignarius, $P$. herreri and $P$. chinai were analysed and the significant differences in length and nucleotide composition suggest a relatively old divergence of Panstrongylus species (Marcilla et al., 2002)

Analyses of ITS-2 region and rDNA $18 \mathrm{~S}$ indicated that the divergence between the Triatomini and Rhodniini tribes possibly occurred in the lower Tertiary period and that the Triatomini tribe had a polyphyletic origin. The nucleotide differences between the ITS- 2 sequences of the Triatomini and Rhodniini tribes are numerous, around $85 \%$ of variable positions in the alignment between the analyzed species of Rhodnius and Triatoma (Bargues et al., 2000). The analyses of the ITS-2 region of these tribes also presented significant differences in sequence lengths. Due to the high variation between the sequence alignments the tribes were considered separately (Marcilla et al., 2001). AFLP analysis of ITS-1 ribosomal transcribed DNA intergenic spacer on Rhodnius, Triatoma and Panstrongylus species reinforced the idea of polyphyletic origin between Rhodniini and Triatomini tribes (Tartarotti \& Ceron, 2005).

The monophyletic origin is well understood in the Rhodnius genus. This group of species possesses similar characteristics and would have originated from a common ancestral species. It is postulated that the Rhodnius genus appeared in the Amazonian region during the Quaternary period. Probably, the closest species of the Reduviidae ancestry is the $R$. pictipes species, which inhabits the Bromeliads and a variety of palm tree. Other species of Rhodnius are more specialized and can be considered to be derived from $R$. pictipes (Schofield \& Dujardin 1999).

The similarity between Rhodnius species is so great that one species is frequently mistaken for another, due to their morphologic similarity. $R$. prolixus, $R$. robustus, $R$. neglectus and $R$. nasutus belong to the Prolixus complex, it being difficult to differentiate $R$. robustus from $R$. prolixus. The Peruvian $R$. robustus populations are inter-fertile with $R$. prolixus populations from Honduras, Colombia and Venezuela. Until now 13 Rhodnius species have been described (R. brethesi, R. dalessandroi, $R$. domesticus, $R$. ecuadoriensis, $R$. nasutus, $R$. neglectus, $R$. neivai, $R$. pallescens, $R$. paraensis, $R$. pictipes, $R$. prolixus, $R$. robustus and $R$. stali). These species are classified in the Rhodniini tribe together with the Psammolestes genus. The classification of Rhodiniini, as a monophyletic tribe, takes into account characteristics of the Rhodnius genus not shared with other triatomines, such as, apical antenna insertion, body forms, post-ocular callosities, male genital characteristics, egg surface architecture and nitroforine presence in the salivary glands. Besides these characteristics, the Rhodnius and Psammolestes genera are primarily arboreal species in contrast with the terrestrial habits of most of the other triatomines 
(Schofield \& Dujardin, 1999) and studies of sequence of ribosomic RNA mitocondrial and cytocrome B genes cluster Psammolestes coreodes with the species Rhodnius prolixus, $R$. robustus and $R$. neglectus (Lyman, 1999). One Phylogenetic study in eleven Rhodnius species and one of Psammolestes compared by DNA sequence analysis of mitochondrial ribosomal RNA, mitochondrial cytochrome $b$ and nuclear RNA. The results revealed two clades within the Rhodniini; one including the prolixus group of species together with Rhodnius domesticus and Rhodnius neivai and other comprising two groups formed by Rhodnius pictipes plus Rhodnius brethesi, and $R$. ecuadoriensis plus Rhodnius pallescens. Psammlestes tertius appeared most closely related to the prolixus group. This study indicated a paraphyletic nature of the Rhodnius genus and supporting the monophyly of the Rhodniini tribe (Monteiro et al., 2000)

Currently the most widely accepted hypothesis is that triatomines represent a polyphyletic group, defined on the basis of their convergent apomorphic hematophagy characters which have appeared several times in Reduviidae. These insects are highly adaptable to different habitats and the constant expansion by animals or humans. The hypothesis of polyphyletic evolution is corroborated by several studies on the Rhodiniini and Triatomini tribes. Analyses of sequences of mitochondrial (Stothard et al., 1998; Lyman, 1999) and ribosomal DNA (Bargues et al., 2000; Marcilla et al., 2001) and analysis of polymorphism length of intergenic transcribed rDNA (Tartarotti \& Ceron 2005), enzymatic studies, morphological analyses and taxonomic (Carcavallo, 1999), ecological studies (Schofield, 1988), all support the theory of polyphyletic evolution. Thus, the Triatominae subfamily may be defined as a grouping based on hematophagous feeding with predatorial Reduviidae ancestry dispersed to several areas of the world.

\section{REFERENCES}

BARGUES, M. D., MARCILLA, A., RAMSEY, J. M., DUJARDIN, J. P., SCHOFIELD, C. J. \& MAS-COMA, S., 2000, Nuclear rDNA-based molecular clock of the evolution of Triatominae (Hemiptera: Reduviidae), Vectors of Chagas disease. Mem. Inst. Oswaldo Cruz, 95: 567-573.
CARCAVAlLO, R. U., JURBERG, J. \& LENT, H., 1999, Phylogeny of the triatominae, pp. 925-965. In: R. U. Carcavallo, I. G. Girón, J. Jurberg, L. Lent (eds.), Atlas of Chagas disease vectors in the Americas, $3^{\circ}$ vol. 485 p., Rio de Janeiro.

DUJARDin, J. P., MUÑOZ, M., CHAVEZ, T., PONCE, C., MORENO \& J. SCHOFIELD, C. J., 1998, The origin of Rhodnius prolixus in Central America. Medical and Veterinary Entomology, 12: 113-115.

FORATTINI, O. P., 1980, Biogeografia, origem e distribuição da domiciliação de triatomíneos no Brasil. Rev. Saúde Publ., 14: 265-299.

GAlvão, C., CARCAVAllo, R., ROCHA, D. S. \& JURBERG, J. A., 2003, A checklist of the current valid species of the subfamily Triatominae Jeannel, 1919 (Hemiptera, Reduviidae) and their geographical distribution, with nomemclatural and taxonomic notes. Zootaxa, 202: 1-36.

GAUNT, M. \& MILES, M., 2000, The ecotopes and evolution of triatomine bugs (triatominae) and their associated Trypanosomas. Mem. Inst. Oswaldo Cruz, 95: 557-565.

GORLA, D. E., DUJARDIN, J. P. \& SCHOFIELD, C. J., 1997, Biosystematics of Old Word Triatominae. Acta Tropica, 127-140.

LENT, H. \& WYGODZINSKY, P., 1979,. Revision of the Triatominae (Hemiptera, Reduviidae), and their significance as vectors of Chagas'disease. In: L. Herman and Wygodzinsky (eds.), Bull. Am. Mus. Nat. Hist., v. 163, n. 3, 520p., New York.

LYMAN, D. F., MONTEIRO, F. A., ESCALANTE, A. A., CORDON-ROSALES, C., WESSON, D. M., DUJARDIN, J. P. \& BEARD, C. B., 1999, Mitochondrial DNA sequence variation among Triatomine vectors of Chagas' disease. Am. J. Trop. Med. Hyg., 60: 377-386.

MARCILLA, A., BARGUES, M. D., RAMSEY, J. M., MAGALLON-GASTELUM, E., SALAZAR-SCHETTINO, P. M., ABAD-FRANCH, F., DUJARDIN, J. P., SCHOFIELD, C. J. \& MAS-COMA, S., 2001, The ITS-2 of the nuclear rDNA as a molecular marker for populations, species and phylogenetic relationships in triatomianae (hemiptera: Reduviidae), vectors of Chagas Disease. Molecular Phylogenetics and Evolution, 18: 136-142.

MARCILLA, A., BARGUES, M. D., ABAD-FRANCH, F., PANZERA, F., CARCAVALLO, R. U., GALVÃO, C., JURBERG, J., MILES, M. A., DUJARDIN, J. P. \& MAS-COMA, S., 2002, Nuclear rDNA ITS-2 sequences reveal polyphyly of Panstrongylus species (Hemiptera: Reduviidae:Triatominae), vectors of Trypanosoma cruzi. Infect. Genet. Evol., 1: 225-235.

MONTEIRO, F. A. , WESSON, D. M., DOTSON, E. M., SCHOFIELD, C. \& BEARD, C. B., 2000, Phylogeny and Molecular taxonomy of the Rhodniini derived from mitochondrial and nuclear DNA sequences. Am. J. Trop. Med. Hyg., 62: 460-465.

SCHOFIELD, C. J., 2000, Trypanosoma cruzi- The vectorparasite paradox. Mem. Inst. Oswaldo Cruz, 95: 535-544.

SCHOFIELD, C. J. \& DUJARDIN, J. P., 1999, Theories on the evolution of Rhodnius. Actual Biol., 21: 183-197. 
SCHOFIELD, C. J. \& DOLLING, W. R., 1993, Bedbugs and Kissing-bugs (bloodsucking Hemiptera). pp. 483-516. In: LR. P. Lane nad R. W. Crosskey (eds.), Medical insects and arachinids. Chapman and Hall, New York.

SCHOFILELD, C. J., 1988, Biosystematics of the triatominae. Biosystematics of Haematophagous insects, 37: 284-312.

STOTHARD, J. R., YAMAMOTO, Y., CHERCHI, A., GARCIA, A. L., VALENTE, S. A. S., SCHOFIELD, C. J. \& MILES, M. A. A., 1998, Preliminary survey of mitochondrial sequence variation in Triatominae (Hemiptera: Reduviidae) using polymerase chain reaction-based single strand conformational polymorphism (SSCP) analysis and direct sequencing. Bulletin of Entomological Research, 88: 553-560.

TARTAROTTI, E. \& CERON, C. R., 2005, Ribosomal ITS1 DNA Intergenic Spacer Polymorphism in Triatomines (Triatominae, Heteroptera), Biochemical Genetic, 43(7/8): 365-373.

USINGER, R., WYGODZINSKY, P. \& RYCKMAN, R. E., 1966, The Biosystematics of Triatominae. Annual Review of Entomology, 11: 309-330. 